\title{
LOCAL WISDOM OF SABANG ISLAND SOCIETY (ACEH, INDONESIA) IN BUILDING ECOLOGICAL INTELLIGENCE TO SUPPORT SUSTAINABLE TOURISM
}

\author{
Dian ASWITA* \\ Yogyakarta State University, Indonesia \\ e-mail: aswita_dian@yahoo.com \\ I Gusti Putu SURYADARMA \\ Faculty of Mathematics and Natural Sciences \\ Yogyakarta State University, Indonesia, e-mail: samodhaya@yahoo.com \\ Slamet SUYANTO \\ Faculty of Mathematics and Natural Sciences \\ Yogyakarta State University, Indonesia, e-mail: slametsuyanto@yahoo.com
}

\begin{abstract}
Citation: ASWITA, D., SURYADARMA, I. G. P., SUYANTO, S. (2018). LOCAL WISDOM OF SABANG ISLAND SOCIETY (ACEH, INDONESIA) IN BUILDING ECOLOGICAL INTELLIGENCE TO SUPPORT SUSTAINABLE TOURISM, GeoJournal of Tourism and Geosites. 22(2), 393-402. https://doi.org/10.30892/gtg.22210-297
\end{abstract}

\begin{abstract}
One of the existing natural and environmental uses in Aceh (Indonesia) is tourism. Among the aspects that determine the development and sustainability of tourism are the institutional and community aspects. Sustainable tourism is a picture of both the ecosystem sustainability and socio-economic development of the community. This study aims to reveal and find out the local wisdom practices and explore local knowledge owned by Sabang Island community in managing and conserving of the environment to support the realization of sustainable tourism. This study uses rationalistic paradigm and qualitative research method. The data that has been collected is analyzed descriptively. The local wisdom and local knowledge are reflected in how society has a unique way of looking at and understanding of the nature and interacting with it. In the Aceh community, there are customary institutions that regulate the rules or interactions of the community with the environment, including "panglima laot", "keujreun blang", "peutua seuneubok", "pawang glee or peutua uteun", "haria peukan" and "syahbanda". Local wisdom and local knowledge have great potential in maintaining, preserving and sustainability of the environment used by communities to meet their living needs. Ecological, social, and religious intelligence formed through local wisdom and local knowledge are the functional aspects in maintaining environmental sustainability in order to build sustainable tourism on Sabang Island.
\end{abstract}

Key words: local wisdom, Aceh traditional regulation, Sabang people, ecological intelligence, sustainable tourism

* Corresponding author 


\section{INTRODUCTION}

Aceh is one of the provinces in Indonesia which has a high biodiversity of flora and fauna. Those diversities spread throughout the Aceh province, both in the lowlands, highlands, and coastal and marine areas. The people of Aceh have the authority and equal opportunity in utilizing natural resources so that they can fulfil their needs while complying with the rules and norms that have been established and applied in the society. One formation in using of the nature and the environment in Aceh is the use of tourism, where the potential for tourism development has already started its analysis since 1980 . This matter is obviously seen in the study conducted by a research team from the Department of Education and Culture of Aceh Province (1995), which explains that the Aceh Province is one of the tourist destinations in Indonesia and has attractiveness for domestic and foreign tourists. Besides a natural tourism, the Aceh Province also has a variety of other interesting tourism types and forms such as cultural tourism, historical tourism, religious tourism, culinary tourism, and other special interest tourism.

One of the tourism destinations in Aceh which is well-known to foreign countries is the island of Sabang. Geographically, Sabang Island located between $5^{\circ} 46^{\prime} 28^{\prime \prime}$ to $5^{\circ} 54^{\prime} 28^{\prime \prime}$ north latitude and $95^{\circ} 13^{\prime} 12^{\prime \prime}$ until $95^{\circ} 22^{\prime} 36^{\prime \prime}$ east longitude with an average elevation of 28 meters above sea surface (BPS, 2016), by administrative region includes five islands, namely Weh Island with an area of $151.752 \mathrm{~km}^{2}$; Rubiah Island with an area of $0,357 \mathrm{~km}^{2}$; Seulako Island with an area of $0.055 \mathrm{~km}^{2}$; Klah Island with an area of $0.186 \mathrm{~km}^{2}$; and Rondo Island with an area of $0.650 \mathrm{~km}^{2}$ (see Figure 1). The tourism sector is the dominant sector in regional development programs in the Sabang island, which is not only used to increase foreign exchange and regional income but also become one of the mainstays to improving the income of local people.

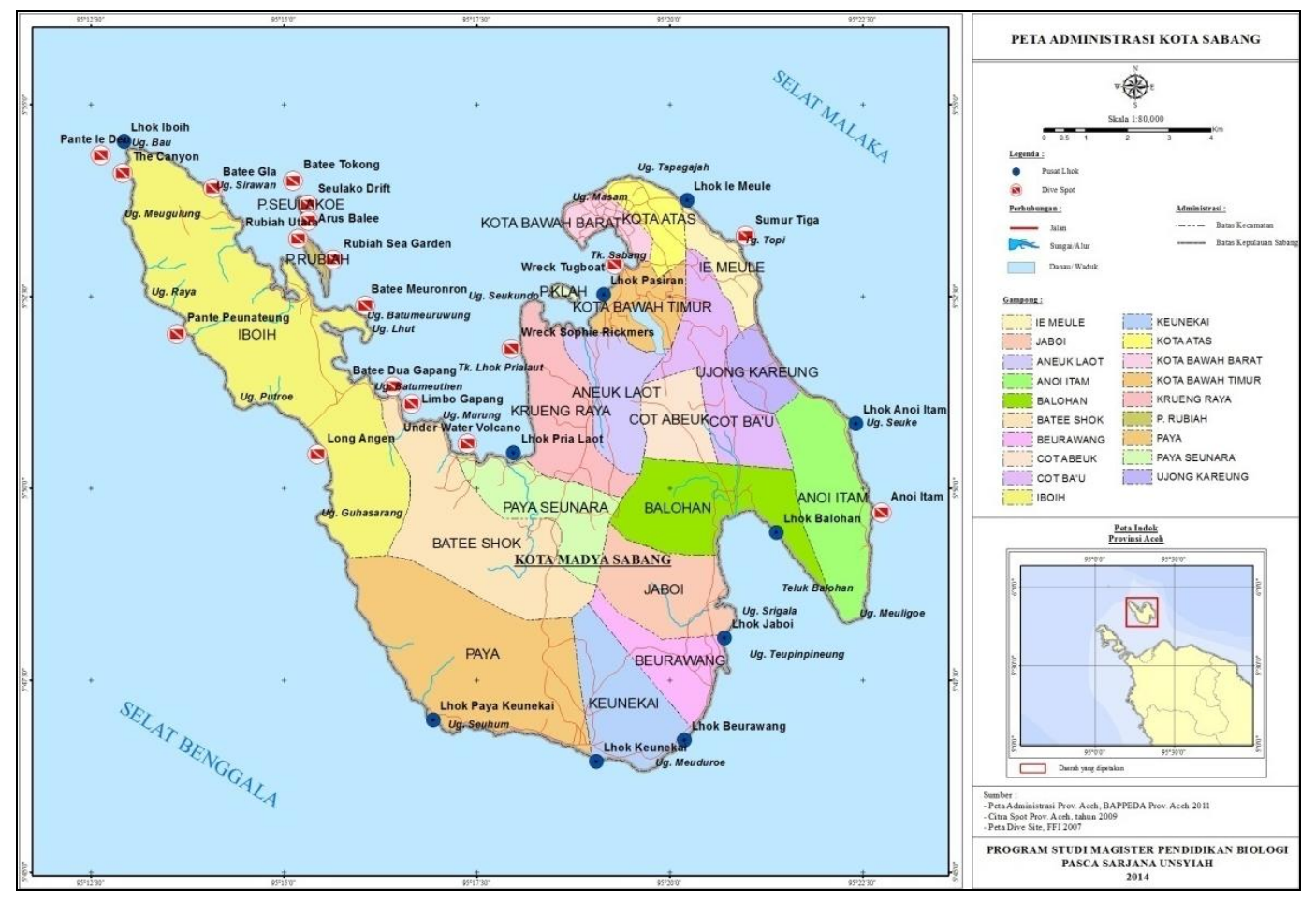

Figure 1. Administrative Map of Sabang Island (Source: Aswita, 2014) 
From Figure 1, Sabang Island has some of the most interesting diving spots. The main tourism object which is very well known and much visited by tourist is a natural tourism is oriented in Rubiah Island nautical tourism of marine park, Paradiso Beach, Iboih Beach, Gapang Beach, Sumur Tiga Beach, with various activities done like diving, snorkelling, swimming, fishing and sunbathing on the shore. It is also described by Ramadhani and Rusyana (2010) in their research about Sabang tourism, the most attractive location is Gapang Beach, Tugu KM O, and Iboih Beach, with the main activities of travelers in a row, people are visiting the beach, diving/swimming, visiting the historical places, fishing, and shopping. It is also reported by Syahnur and Herlina (2015) in their research. Furthermore, Chan (2016), also mentioned that the most fascinating and most favourable attractions on Sabang Island are under the sea. More than 19 diving spots are scattered throughout the region that has natural beauty, ranging from exotic coral, fish, and other marine life. One of the most interesting diving spots is the ruins of the ship Sophie Rickmers who drowned during World War II. This place is known as Sophie Rickmers Wreck WM II, where there are many fish of various types and colour, who chose this shipwreck as their "home". Besides the marine tourism, Sabang Island also has several natural tourism attractions or landscape and culture which are very interesting, namely the park forest tourism, seashore landscape tourism, volcanic tourism and hot mud, hydrothermal, waterfall, thermal bathing places, lake, heritage, the grave of foreign victim of World War II, and religious sites. One aspect that determines the development and sustainability of tourism are the institutional and social aspects.

Sustainable tourism is a description of the sustainability of ecosystems and social economic development of society. Economically, sustainable tourism has a relationship with the ability of society to manage the existing economic potential. Then ecological sustainability has relevance to the ability of society to manage the natural resources that exist. It means that the empowerment of society and the capacity of the environment (ecology) is needed in the economic improvement and development. Fennel (1999) states that sustainable tourism has several objectives, namely: (1) the establishment of an understanding and higher awareness that tourism can contribute significantly to the preservation and economic development; (2) improve the balance of development; (3) improve the quality of life for local people; (4) improve the quality of understanding for visitors and tourists; and (5) improve and conserve the environmental quality for the next generations. The existence of society in sustainable development cannot be separated at all. Almost all societies have their own procedures to interact, relate, and use the environment which is different in each region. Traditions, customs, and the order of the local cultural values serve as a guide and benchmark for people in everyday life. The procedure is often interpreted as local wisdom. Dahliani, Soemarno, and Setijanti (2015) state that local wisdom is the culture which is produced from human thought processes to adjust its presence in nature that can be embodied in concrete works in the use of the environment. Local wisdom is always changing because it follows the cultural dynamics and cannot be separated from the human mindset. Besides that, Mungmachon (2012), also states that local wisdom is the basic knowledge gained from living in balance with nature. This is related to the culture in the society which is accumulated and inherited. This policy can be abstract and concrete, but the essential characteristic is that it comes from experience or truth gained from life. Nasir (2013), say that "local wisdom is a form to find the format of values that grow in a society".

Local wisdom is also often conceived as local knowledge because local wisdom and local knowledge have the same meaning. Although the terms are different, both are clear that local knowledge is the result of man as a cultural process in accordance with the 
surrounding natural environment. Connection with nature, the main factor to be considered, is acquired in a long period of time and is passed from generation to generation (Dahliani, Soemarno, and Setijanti, 2015). WIPO (2002) defines local knowledge by citing explanations from Warren (1991), i.e., the knowledge that is unique to a given culture or society. It contrasts with the international knowledge system generated by universities, research institutions and private firms. It is the basis for locallevel decision making in agriculture, health care, food preparation, education, natural resource management, and a host other activities in rural communities.

In daily life, Sabang community has regulations which are provided in the customary form, which includes habits, obligations and restrictions which will be a guidance in their behaviour with their surroundings. These regulations are inherited from ancestors and should be passed and guarded carefully. Because for them it can maintain the balance of the relationship between human and nature in order to maintain the life sustainability. In addition, the environment that they live it constitutes one of the destinations and the development of tourism in Aceh. Then, to anticipate the widespread of exploitation activity and the disharmonious of community behaviour, so that the positive role society in managing and conserving environment is to be important.

This study aims to describe and discover the practice and explore the existence of local wisdom possessed by the people of Sabang Island in the management and preservation of the environment that supports the realization of sustainable tourism.

\section{METHODOLOGY}

This study used a rationalistic paradigm that was a research which analyzes based on the reality on the field using the analysis of qualitative methods (Moleong, 2007). The qualitative research then followed by qualitative research. The qualitative research was a process of research to find social and humanitarian issues based on efforts to build a complex and comprehensive description, formed by words or description, by containing detailed views from the resources. The data was collected by interview technique, observation, and analyzing and reviewing secondary data. The data then analyzed descriptively. The qualitative data was then processed inductively by using an interactive analysis model (Miles \& Huberman, 1994).

\section{RESULT AND DISCUSSIONS}

The environmental crisis is an environmental issue that appears naturally as well as caused by human itself. However, the human factor becomes the biggest cause of environmental problems and it may arise from the direct action in the utilization of the environment or from the effects that arise in the long term use of the environment. The environmental crisis is caused by three things, that are (1) the paradigm of man against nature, where the paradigm in this matter includes the way people understand and relate to nature; (2) the modernity, which is understood as an era and a way of human thinking who see nature exist for the good of man; and (3) the industrialism, the product of both of them and have a tendency to exploit the nature itself (Simbolon, 2014).

As a result of the continuation of human interaction with nature, and to answer some issues arising from the interaction, then there is an awareness that appears to create a harmonious relationship between humans and nature. Local wisdom and local knowledge reflected from how society has a unique way of viewing and understanding of nature as well as interacting with it. In Aceh society, there are traditional institutions that regulate the procedure or society's interaction with the environment, where each institution is led by one leader cultures, among them are "panglima laot", "keujreun blang", "peutua 
seuneubok", "pawang glee or peutua uteun”, "haria peukan" and "syahbanda". The job descriptions of each of the traditional institutions have been established and elaborated in Qanun Aceh Nomor 10 Tahun 2008 about Lembaga Adat, is as follows (Table 1).

Table 1. Indigenous Institutions in Aceh Society that Regulate Human Interaction and the Environment (Data source: Aceh Traditional Regulated (Qanun Number 10 Year 2008)

\begin{tabular}{|c|c|c|}
\hline \begin{tabular}{|c|} 
Indigenous \\
Institutions \\
Name
\end{tabular} & Title for & Authorities, Duties, and Functions \\
\hline $\begin{array}{l}\text { Panglima } \\
\text { Laot }\end{array}$ & $\begin{array}{l}\text { People who lead and } \\
\text { manage the customs in } \\
\text { the field of coastal and } \\
\text { marine areas }\end{array}$ & $\begin{array}{l}\text { Panglima Laot Authorities } \\
\text { a)determining the order of fishing include determining the } \\
\text { results and the days of avoidance fishing; } \\
\text { b)resolving the dispute of indigenous and problem } \\
\text { among fisherman; } \\
\text { c)resolving the dispute of indigenous that occur } \\
\text { between Laot lhok; } \\
\text { d)coordinating the implementation of Laot customary law, } \\
\text { increasing resources and the advocacy policy of marine } \\
\text { and fisheries sector to increase the welfare of fishermen. } \\
\text { Panglima Laot Duties } \\
\text { a)implementing, maintaining and supervising the } \\
\text { implementation of the customs and Laot customary law; } \\
\text { b)assisting the Government in the field of fisheries and } \\
\text { marine areas; } \\
\text { c)resolving the dispute and discord between fishermen in } \\
\text { accordance with the Laot customary law; } \\
\text { d)protecting and preserving the environmental function } \\
\text { of coastal and marine areas; } \\
\text { e)struggling for the improvement of the lives of fishing } \\
\text { communities; } \\
\text { f)preventing illegal fishing. }\end{array}$ \\
\hline $\begin{array}{l}\text { Keujreun } \\
\text { Blang }\end{array}$ & $\begin{array}{l}\text { People who lead and } \\
\text { organize activities in } \\
\text { the field of paddy sector }\end{array}$ & $\begin{array}{l}\text { Keujreun Blang Duties } \\
\text { a)determining and coordinating the ordinances of going } \\
\text { to the field; } \\
\text { b)regulating the distribution of water to farmers' paddy; } \\
\text { c)assisting the government in the field of agriculture; } \\
\text { d)coordinating khanduri or other ceremonies related to } \\
\text { the customs in the agricultural fields; } \\
\text { e)giving a warning or sanction to farmers who violate } \\
\text { the rules of indigenous meugoe (paddy) or do not obey } \\
\text { other obligations in the implementation of the system } \\
\text { of indigenous paddy farming; } \\
\text { f)resolving the dispute between farmers relating to the } \\
\text { implementation of the agricultural fields. }\end{array}$ \\
\hline $\begin{array}{l}\text { Peutua } \\
\text { Seuneubok }\end{array}$ & $\begin{array}{l}\text { The person who leads } \\
\text { and regulates the } \\
\text { customary provision } \\
\text { about the opening and } \\
\text { using of land for } \\
\text { cultivation/plantation. }\end{array}$ & $\begin{array}{l}\text { Peutua Seuneubok Duties } \\
\text { a)arranging and dividing the land within the Seuneubok area; } \\
\text { b)assisting the government's tasks in the fields of } \\
\text { plantations and forestry; } \\
\text { c)administering and supervising the implementation of } \\
\text { traditional ceremonies within the area of Seuneubok; } \\
\text { d)resolving the dispute which occurs within the area of } \\
\text { Seuneubok; } \\
\text { e)implementing and maintaining the customary law } \\
\text { within the area of Seuneubok. }\end{array}$ \\
\hline
\end{tabular}




\begin{tabular}{|l|l|l|}
\hline $\begin{array}{l}\text { Pawang } \\
\text { Glee } \\
\text { or } \\
\begin{array}{l}\text { Peutua } \\
\text { Uteun }\end{array}\end{array}$ & $\begin{array}{l}\text { The person who leads } \\
\text { and regulates customs } \\
\text { regarding the } \\
\text { management and } \\
\text { preservation of the } \\
\text { forest environment }\end{array}$ & $\begin{array}{l}\text { Pawang Glee Duties } \\
\text { a)leading and managing the customs which relate to the } \\
\text { management and preservation of the forest environment; } \\
\text { b)assisting the government in forest management; } \\
\text { c)enforcing customary laws on forests; } \\
\text { d)coordinating the implementation of customary } \\
\text { ceremonies which relate to forests; } \\
\text { e) resolving the dispute between citizens in the forest utilization }\end{array}$ \\
\hline $\begin{array}{l}\text { Haria } \\
\text { Peukan }\end{array}$ & $\begin{array}{l}\text { The person who governs } \\
\text { the provisions of custom } \\
\text { about market order, } \\
\text { orderliness, security, } \\
\text { and hygiene of the } \\
\text { market and performs } \\
\text { the assistance tasks }\end{array}$ & $\begin{array}{l}\text { Haria Peukan Duties } \\
\text { a)assisting the government in regulating market order, } \\
\text { orderliness, security, and performs the assistance tasks; } \\
\text { b)enforcing custom and customary law in the } \\
\text { implementation of various activities Peukan; } \\
\text { c)maintaining Peukan hygiene; } \\
\text { d)resolving the dispute that occurred in Peukan. }\end{array}$ \\
\hline Syahbanda & $\begin{array}{l}\text { The person who leads and } \\
\text { regulates customary } \\
\text { provisions on ship/boat } \\
\text { moorings, outbound, and } \\
\text { incoming traffic on ship/boat } \\
\text { in seas, lakes, and rivers that } \\
\text { are not managed by the } \\
\text { Government. }\end{array}$ & $\begin{array}{l}\text { Syahbanda Duties } \\
\text { a)managing the utilization of public ports; } \\
\text { b)maintaining order, security in the harbour area of the } \\
\text { people; } \\
\text { c)resolving the dispute which occurs in people's port } \\
\text { areas; } \\
\text { d)regulating the right and obligation which relate to } \\
\text { harbour utilization. }\end{array}$ \\
\hline
\end{tabular}

The local wisdom and local knowledge of Sabang Island society in interacting and preserving the environment are shown in Table 2. below:

Table 2. Local Wisdom and Local Knowledge People

of Sabang Island in Interacting and Preserving the Environment

\begin{tabular}{|c|c|c|c|}
\hline \begin{tabular}{|c|} 
Local Wisdom \\
and (or) Local \\
Knowledge
\end{tabular} & $\begin{array}{l}\text { Intention and } \\
\text { Restriction }\end{array}$ & $\begin{array}{c}\text { Ecological } \\
\text { Intelligence }\end{array}$ & $\begin{array}{l}\text { Social and Religious } \\
\text { Intelligence }\end{array}$ \\
\hline $\begin{array}{l}\text { Kenduri } \\
\text { Laot }\end{array}$ & $\begin{array}{l}\text { - Prohibition to go to sea for } \\
3 \text { days, starting on the first } \\
\text { day of Kenduri Laot event } \\
\text {-Prohibition of beach } \\
\text { tourism }\end{array}$ & $\begin{array}{l}\text {-Allowing aquatic biota } \\
\text { (eg. fish) to breed, } \\
\text { incubate eggs, and grow } \\
\text { into adulthood. }\end{array}$ & $\begin{array}{l}\text { - Providing an opportunity } \\
\text { for tourists to respect the } \\
\text { local custom } \\
\text { - Increasing the sense of } \\
\text { brotherhood (togetherness) }\end{array}$ \\
\hline $\begin{array}{l}\text { Hari } \\
\text { Pantang } \\
\text { Melaot }\end{array}$ & $\begin{array}{l}\text {-Prohibition to go to sea } \\
\text { every Friday, starting from } \\
\text { Thursday night, until } \\
\text { Friday Prayer is finished } \\
\text { - Restriction on beach tourism } \\
\text { on Friday morning until } \\
\text { Friday Prayers are Finished }\end{array}$ & $\begin{array}{l}\text {-Allowing aquatic biota } \\
\text { (eg. fish) to breed, } \\
\text { incubate eggs, and grow } \\
\text { into adulthood. }\end{array}$ & $\begin{array}{l}\text {-Providing an } \\
\text { opportunity for tourists } \\
\text { to be able to respect the } \\
\text { local custom and } \\
\text { religious activities } \\
\text {-Preparing for Friday } \\
\text { prayer (for Muslims) }\end{array}$ \\
\hline $\begin{array}{l}\text { Meupayang } \\
\text { (Fishing } \\
\text { System) }\end{array}$ & $\begin{array}{l}\text {-Prohibition of trawl usage } \\
\text {-Prohibition of using nets } \\
\text { in certain areas } \\
\text {-Prohibition of using } \\
\text { explosives / other } \\
\text { chemicals } \\
\text {-Prohibition of poison } \\
\text { water flow (river flow) }\end{array}$ & $\begin{array}{l}\text {-Avoiding overfishing } \\
\text { - Avoiding excessive } \\
\text { coral reef damage } \\
\text {-Avoiding pollution of the } \\
\text { water and the environment } \\
\text {-Avoiding pollution of rivers } \\
\text { that empty into the sea and } \\
\text { surrounding environment }\end{array}$ & $\begin{array}{l}\text { - Growing a sense of } \\
\text { concern for the } \\
\text { environment by working } \\
\text { together to protect the } \\
\text { environment }\end{array}$ \\
\hline
\end{tabular}


Local Wisdom of Sabang Island Society (Aceh, Indonesia)

in Building Ecological Intelligence to Support Sustainable Tourism

\begin{tabular}{|c|c|c|c|}
\hline Fishing Area & $\begin{array}{l}\text { - Banning on fishing in } \\
\text { spawning areas and } \\
\text { conservation areas }\end{array}$ & $\begin{array}{l}\text {-Avoiding overfishing } \\
\text {-Avoiding exploitation } \\
\text { of protected fish and } \\
\text { other marine biotas } \\
\text { - Providing opportunities } \\
\text { for fish and other marine } \\
\text { biotas to grow and develop }\end{array}$ & $\begin{array}{l}\text {-Growing a sense of } \\
\text { concern for the } \\
\text { environment by working } \\
\text { together to protect the } \\
\text { environment }\end{array}$ \\
\hline $\begin{array}{l}\text { Land } \\
\text { Opening } \\
\text { System }\end{array}$ & $\begin{array}{l}\text {-The ban on cutting trees at } \\
\text { a radius of about } 500 \text { m. } \\
\text { from the shore of the lake, } \\
200 \mathrm{~m} \text {. from the edge of the } \\
\text { springs and left-right rivers } \\
\text { in the swamp area, about } \\
100 \mathrm{~m} \text {. from the left-right of } \\
\text { the river, about } 50 \mathrm{~m} \text {. from } \\
\text { the edge of the creek (Alue). }\end{array}$ & $\begin{array}{l}\text {-Avoiding } \\
\text { environmental damage } \\
\text { due to land clearing }\end{array}$ & $\begin{array}{l}\text { - Growing a sense of } \\
\text { concern for the } \\
\text { environment by working } \\
\text { together to protect the } \\
\text { environment }\end{array}$ \\
\hline $\begin{array}{l}\text { Peudong } \\
\text { Jambô }\end{array}$ & $\begin{array}{l}\text {-Prohibition of setting up } \\
\text { huts (landed places on } \\
\text { land) on wild animal } \\
\text { tracks or places believed } \\
\text { to be spirits of the jungle. } \\
\text {-Materials used for buffer } \\
\text { huts should also not use the } \\
\text { wood of the roots (uroet), as } \\
\text { it is feared will invite snakes } \\
\text { into the Jambô. }\end{array}$ & $\begin{array}{l}\text {-Avoiding development } \\
\text { in the migratory areas } \\
\text { of animals. } \\
\text {-Avoiding the use of } \\
\text { materials that are the } \\
\text { habitat of an animal }\end{array}$ & $\begin{array}{l}\text { - Growing a sense of } \\
\text { concern for the } \\
\text { environment by working } \\
\text { together to protect the } \\
\text { environment }\end{array}$ \\
\hline $\begin{array}{l}\text { Pantang } \\
\text { daruet }\end{array}$ & $\begin{array}{l}\text {-It is forbidden to hang a } \\
\text { cloth on a tree and to set } \\
\text { a machete on a tree stump } \\
\text { - Do not cut (ceumeucah) } \\
\text { in the rain }\end{array}$ & $\begin{array}{l}\text {-Avoiding making } \\
\text { incisions, damage that } \\
\text { makes plants feel pain } \\
\text { - Eliminating the aesthetics } \\
\text { of plants and environment. } \\
\text {-Avoiding the destruction } \\
\text { of grasshopper habitat } \\
\text { (daruet) that will eventually } \\
\text { end up like pests } \\
\end{array}$ & $\begin{array}{l}\text { - Growing a sense of } \\
\text { concern for the } \\
\text { environment by working } \\
\text { together to protect the } \\
\text { environment } \\
\text { - Having a sense of } \\
\text { affection towards other } \\
\text { living things }\end{array}$ \\
\hline $\begin{array}{l}\text { Gotong } \\
\text { Royong } \\
\text { Activities }\end{array}$ & $\begin{array}{l}\text { - Gotong royong activities, } \\
\text { both on the commemoration } \\
\text { of religious holidays and state } \\
\text { holidays, marriage ceremonies, } \\
\text { deaths, post-fishing, and } \\
\text { post-harvest rice fields }\end{array}$ & $\begin{array}{l}\text { - Maintaining } \\
\text { cleanliness of the } \\
\text { environment and } \\
\text { cultivate a sense of } \\
\text { concern for the } \\
\text { environment }\end{array}$ & $\begin{array}{l}\text { - Fostering a social sense } \\
\text { of community } \\
\text { (togetherness) } \\
\text {-Creating harmonization } \\
\text { and harmony of life to } \\
\text { the community }\end{array}$ \\
\hline
\end{tabular}

The human survival depends on how people interact and relate to nature and the environment. Local wisdom is all forms of knowledge, belief, understanding or insight, customs, and ethics of guiding human in behaving with the ecological community during his lifetime. Local wisdom is holistic because it deals with the knowledge, understanding and human insight in a relationship with nature and the environment. Kongprasertamorn (2007), states that, in order to live in harmony with the environment, local society use the accumulated local wisdom that derives from their ancestors to manage natural resources. Utilization of local wisdom can be seen in terms of daily activities. In addition, Brook \& McLachlan (2008), states that the use of local knowledge gives a lot of opportunities that are diverse in ecological research and conservation. 
Local wisdom and local knowledge that is used by the island of Sabang (Table 2), has great potential in maintaining, preserving and environmental sustainability u sed by the society to fulfil their needs, including the improvement of the economy through tourism. Moreover, the tourism object offered is nature tourism, marine tourism, adventure tourism, historical tourism, religious tourism, culinary tourism, and other special interest tourism. Thus, the existence of local wisdom and local knowledge can be an aspect in maintaining the environmental sustainability in order to build a sustainable tourism on the island of Sabang.

The same thing is also described by Singsomboon (2014), he finds that, in Thailand, local wisdom has been employed to promote tourism thought creative tourism process and to create conservation and development in various forms of projects. Using local wisdom to promote tourism through creative tourism process in order to create sustainable tourism development is targeted at the community. Equilibrium must be created in terms of economy, society and environment so that the community, with this equilibrium, can develop sustainable tourism. The concept of sustainable development that focuses on people-centered is applied to create equilibrium, stability and sustainability in these 4 sides; 1) Life - human from individual, family and community level are affected by external environment, resulting in risks and instability, 2) Economy of people in the community, 3) Society - community and society of human beings living together, having relationship and responsibility in the change of the society and 4) Environment around human beings and social environments.

The potential of local wisdom also gives a different opportunity in tourism that is cultural tourism. Cultural tourism in Sabang Island is also demanded by tourists because it offers a different form of tourism. Tourists can enjoy the simple life, peace bound by customary rules. Custom, culture and the religion of society run hand in hand in harmony to form the local identity of the society that inspires society life and interaction among the people residing in it. The existence of local wisdom can be used as a social institution in managing the development of tourism, so as to keep providing an opportunity for local society to maintain the authenticity of custom and culture, although they have interacted with the outside society.

In their study, Yi-fong (2012), discusses the socio-cultural influences of ecotourism, which integrates cultural revitalization, ecological conservation, and social development. Many cases in various parts of the world indicate that indigenous peoples have developed patterns in the use of resources and management practices that reflect the detailed knowledge of local geography and ecosystem and contribute to the conservation of nature through the practice of their lives. For indigenous peoples, to affirm their identity as a media in preserving their cultural identity and to develop their socio-economic potential is the way to survive in the modern industrial world. Environmental sustainability is inevitably tied to the configuration of the structure of economic, social, cultural and political. As the tourism industry gains strength in the economic development strategy, the requirement to involve local society in the process of sustainable tourism management becomes indispensable. Cappucci (2016), based on her research in Suriname, explained that in order to develop and promote sustainable tourism, all relevant stakeholders have to: 1) support the integrity of the place; 2) conserve resources; 3) respect local culture and traditions.

The sustainability concept is also applied in education through education for sustainable development. The concept of sustainability in an educational context is illustrated by Sterling (2001), which identifies the key concepts of sustainable development as follows: 
a. The interdependence of society, economy, and natural environment, from local to global;

b. Citizenship and management, including the rights and responsibilities, participation and conservation;

c. Needs and rights of future generations;

d. In the concept of Cultural, social, economics, and biodiversity;

e. Quality of life, equality, and justice;

f.Changes in sustainable development, and the carrying capacity;

g.Uncertainty and precaution in action

Environmental sustainability, education sustainability, and the sustainability of human life is a unity that cannot be separated one from another, where each dimension contributes to other dimensions. Environmental sustainability is certainly contributing to the sustainability of tourism, which eventually gives its own contribution to the sustainability of human life through economic growth. Environmental sustainability is also inseparable from how local society is habitable by values, rules, and certain norms. Environmental sustainability must also be supported by the development of education in introducing local society about how they should relate to nature, even though they have gained the knowledge and insight from the previous generation, in the form of local wisdom and local knowledge. Aswita (2018), say that "an understanding of environment can be obtained from environmental education, which later becomes a determining factor in people's interaction with their environment". Bâca (2015), say that "because education is the basis for all planning activities, recovery and conservation of natural heritage".

Studies on environmental education and tourism have been conducted by many researchers, such as: Ilieș, et al., (2017), where their study of using Valea Roșie Nature 2000 tourist map in print and digital form as an instrument for environmental education activities. Tisdell \& Wilson (2005), also explores the role of ecotourism in promoting environmental learning and in sustaining conservation of nature.

\section{CONCLUSION}

Local wisdom and local knowledge reflected from how society has a unique way of viewing and understanding of nature as well as interacting with it. In Acehnese society, there are customary institutions that regulate the procedure or society's interaction with the environment, where each institution is led by one leader culture among them are "panglima laot", "keujreun blang", "peutua seuneubok", "pawang glee or peutua uteun", "haria peukan" and "syahbanda". Local wisdom and local knowledge have great potential in maintaining and preserving environmental sustainability used by the society to fulfil its needs. Ecological, social and religious intelligence formed by local wisdom and local knowledge can be an aspect in maintaining environmental sustainability in order to build a sustainable tourism on the Sabang Island.

\section{Acknowledgments}

The author would like to say thank to the society of Sabang City and Department of Culture and Tourism of Sabang, so this research can be done well.

\section{REFERENCES}

Aswita, D. (2014). Mapping and Evaluation of Marine Ecotourism in Teupin Layeu Iboih Beach, Sabang City. Thesis. Banda Aceh: Postgraduate Program of Syiah Kuala University, Aceh, Indonesia, 2014.

Aswita, D. (2018). Environmental Education and Ecotourism for Sustainable Life: Literature Study. JIP-The International Journal of Social Sciences, Vol. 6, No. 1, January 2018. 
Bâca, I. (2015). A Curriculum for Learning Nature Values. Case Study: Learning Geodiversity from Bistriţa Ardeleană Gorge (Bistriţa-Năsăud County, Romania). GeoJournal of Tourism and Geosites Year VIII, no. 1, vol. 15, May 2015, p.14-24, Article no. 15102-155.

Brook, R. K., \& McLachlan, S. M. (2008). Trends and Prospects for Local Knowledge in Ecological and Conservation Research and Monitoring. Biodivers Conserv (2008) 17:3501-3512, DOI 10.1007/s10531-008-9445-x.

Cappucci, M. (2016). Indigenous Tourism in the Amazon Region of Suriname: Actions to Preserve Authenticity and Natural Resources. GeoJournal of Tourism and Geosites, Year IX, No. 1, Vol. 17, p.47-56, Article no. 16104-193, May 2016.

Chan, S. (2016). Evaluation Of International Tourist Satisfaction In Weh Island Indonesia Using HOLSAT Model. International Journal of Scientific \& Technology Research, Vol 5, Issue 05, May 2016.

Dahliani., Soemarno, I., \& Setijanti, P. (2015). Local Wisdom in Built Environment in Globalization Era. International Journal of Education and Research Vol. 3 No. 6 June 2015.

Department of Education and Culture of Aceh Special Region. (1995). Impact of Tourism Development on Social Life in Aceh Special Region. Aceh: Department of Education and Culture of Aceh Province, Directorate of History and Traditional Values. (Depdikbud Provinsi Daerah Istimewa Aceh. (1995). Dampak Pengembangan Pariwisata Terhadap Kehidupan Sosial di Daerah Istimewa Aceh. Aceh: Depdikbud Provinsi Daerah Istimewa Aceh, Direktorat Sejarah dan Nilai Tradisional).

Fennel, D. A. (1999). Ecotourism, An Introduction. New York: Routledge.

Ilieș, D. C., Baias, S., Buhaș, R., Ilieș, A., Herman, G. V., Gaceu, O., Dumbravă, R., \& Măduţa, F. M. (2017). Environmental Education in Protected Areas. Case Study from Bihor County, Romania. GeoJournal of Tourism and Geosites, Year X, no. 1, vol. 19, May 2017, p.126-132, Article no. 19111-235.

Kongprasertamorn, K. 2007. Local Wisdom, Environmental Protection and Community Development: The Clam Farmers in Tambon Bangkhunsai, Phetchaburi Province, Thailand. MANUSYA: Journal of Humanities 10.1, 2007.

Miles, M. B., \& Huberman, A. M. (1994). Qualitative Data Analysis. California: Sage Publications.

Moleong, L. J. (2007). Metodologi Penelitian Kualitatif. Bandung: Remaja Rosdakarya Offset.

Mungmachon, M. R. (2012). Knowledge and Local Wisdom: Community Treasure. International Journal of Humanities and Social Science Vol. 2 No. 13; July 2012.

Naggroe Aceh Darussalam. (2008). Aceh Qanun No. 10 of 2008 concerning Indigenous Institute. (Qanun Aceh Nomor 10 Tahun 2008, tentang Lembaga Adat).

Nasir, M. (2013). Identifying Local Wisdom and Acehnese Women Identity Through Straddling. Prosiding the $5^{\text {th }}$ International Conference On Indonesian Studies: Ethnicity and Globalization. ISSN 2087-0019.

Ramadhani, E., \& Rusyana A. (2010). Correspondence Analysis on Public Service in Sabang Tourism Area. Jurnal Natural, Vol. 10, No. 1, 2010.

Simbolon, S. (2014). Ecological Religion Batak Toba: A Case Study of Sianjur Mula-Mula Village, Samosir Regency Sumatera Utara. (Religi Ekologis Batak Toba: Studi Kasus Desa Sianjur Mula-Mula Kab. Samosir Sumatera Utara). Thesis. Yogyakarya: Postgraduate School, Gadjah Mada University, Indonesia, 2014.

Singsomboon, T. (2014). Tourism Promotion and the Use of Local Wisdom Through Creative Tourism Process. International Journal of Business Tourism and Applied Sciences, Vol.2 No.2 July-December 2014, ISSN2286-9700.

Sterling. S. (2001). Sustainable Education: Re-visioning Learning and Change. Darlington, U.K.: Green Books.

Syahnur, S., \& Herlina. (2015). Visitors' Willingness to Pay for Local Tourist Attractions in Sabang Based on Travel Cost Method. International Journal of Applied Business and Economic Research (IJABER), Vol. 13, No. 7: 5677-5701, 2015.

Tisdell, C., \& Wilson, C. (2005). Perceived Impacts of Ecotourism on Environmental Learning and Conservation: Turtle Watching as A Case Study. Environment, Development and Sustainability (2005) 7: 291-302, DOI 10.1007/s10668-004-7619-6.

Yi-Fong, C. (2012). The Indigenous Ecotourism and Social Development in Taroko National Park Area and SanChan tribe, Taiwan. GeoJournal, Vol. 77, No. 6, pp. 805-815, DOI 10.1007/s 10708-010-9373-7.

*** BPS. (2016). Sabang Municipality in Figures 2016. BPS-Statistics of Sabang Municipality.

*** WIPO. (2002). Intergovernmental Committee on Intellectual Property and Genetic Resources, Traditional Knowledge and Folklore; Traditional Knowledge - Operational Terms and Definitions. Geneva: World Intellectual Property Organization. Available at: http://www.wipo.int/edocs/mdocs/tk/en/wipo_grtkf _ic_3/wipo_grtkf_ic_3_9.pdf.

Submitted:

26.11.2017
Revised:

18.05.2018
Accepted and published online 21.05.2018 